\title{
ПРОБЛЕМА ПРЕЮДИЦИАЛЬНОЙ СИЛЫ РЕШЕНИЙ МЕЖДУНАРОДНЫХ КОММЕРЧЕСКИХ АРБИТРАЖЕЙ В ЗАКОНОДАТЕЛЬСТВЕ РФ
}

\begin{abstract}
Аннотация: В статье рассматривается понятие "преюдиция» - свойство вступившего в законную силу судебного акта, в соответствии с которым, факты, установленные судебным актом, обязательны при рассмотрении иных дел с участием данных сторон. Отдельное внимание в статье уделяется проблеме преюдициальной силы решений международных коммерческих арбитражей. Основываясь на практике ВАС РФ (Определение ВАС РФ № ВАС-17458/11), автор приходит к выводу о том, что решения международных коммерческих арбитражей и решения государственных арбитражных судов обладают равной юридической силой, в соответствии с толкованием ВАС РФ ст. III Нью-Йоркской Конвенции 1958 г. Поскольку решения международных коммерческих арбитражей обладают равной юридической силой, в статье делается вывод о наличии преюдициальной силы у решений международных коммерческих арбитражей, поскольку преюдициальная сила представляет собой неотъемлемое свойство вступившего в законную силу судебного акта. Вывод о наличии преюдициальной силы у решений третейских судов подкрепляется ссылкой на решение ЕСПЧ по делу “Этеш Мимарлик Мюхендишлик против Турции».

Ключевые слова: международный коммерческий арбитраж, преюдиция, ВАС РФ, ЕСПЧ, арбитражное соглашение, правовая определенность, арбитражный прочесс, государственные арбитражные суды, Нью-Йоркская Конвенция, третейский суд
\end{abstract}

DOI: 10.7256/1994-1471.2014.3.9366

\section{Введение}

В теории арбитражного процесса отмечается, что факты, установленные судебным актом или приговором суда по другому делу, не подлежат повторному доказыванию ${ }^{1}$. Для обозначения данного свойства судебного акта используется латинский термин - «преюдиция» (также «преюдициальная сила судебного акта»).

В АПК 2002 г. преюдициальная сила судебных актов закрепляется в ст. 69 АПК, в соответствии с которой сторона освобождается от доказывания обстоятельств, установленных вступившим в законную силу актом арбитражного суда, решением суда общей юрисдикции, а также приговором суда по уголовному дела относительно совершения лицом тех или иных действий.

Специалисты в области арбитражного процесса отмечают, что принцип преюдициальной силы

Новоселова Л.А., Рожкова М.А. К вопросу о силе судебных актов арбитражного суда //Вестник ВАС РФ. 2003. № 5. представляет собой проявление обязательной силы судебного акта (cm. 16 АПК), в соответствии с которой акты арбитражного суда обязательны на всей территории РФ для граждан, организаций и органов государственной власти ${ }^{2}$.

От понятия «преюдициальная сила» следует отличать принцип res judicata, который pacпространяется на ограниченное число случаев, когда сторона заявляет иск по ранее рассмотренному основанию, к тем же сторонам и о том же самом предмете (cm. 150 АПК). Отличие преюдициальной силы от res judicata заключается в том, что обстоятельства, установленные судебным актом, обязательны при рассмотрении всех иных споров между сторонами, независимо от требований, заявляемых ими.

Однако принцип преюдициальной силы и принцип res judicata преследуют общую цель исключить различную оценку (иную правовую квалификацию) одних и тех же фактических обстоятельств при рассмотрении иных споров с

2 Березий А.Е., Мусин В.А. О преюдиции судебных актов //Вестник ВАС РФ. 2001. № 6.

(C) Костин Александр Алексеевич

* Младший юрист юридической фирмы «Хренов и Партнеры»; магистр частного права МГИМО (У) МИД РФ

[akostin16@yandex.ru]

109240, г. Москва, Б. Ватин пер., д. 3. 
участием одних и тех же сторон по делу. Тем самым исключается неопределенность в правах лица, которая неизбежно возникнет, если суды будут по-разному квалифицировать одни и те же фактические обстоятельства.

Совершенно по-иному в РФ регулируются вопросы обязательной силы решений международных коммерческих арбитражей.

Несмотря на то, что в АПК установлен запрет на повторное рассмотрение спора при наличии признанного и приведенного и исполнение решения международного коммерческого арбитража (п. 2 ст. 150 АПК), в АПК отсутствуют положения, освобождающие сторону от доказывания фактов, установленных решением международного коммерческого арбитража.

Однако при этом необходимо учитывать, что в соответствии со ст. III Нью-Йоркской Конвенции 1958 г. решения международных коммерческих арбитражей являются обязательными (курсив-A.К) для договаривающихся государств ${ }^{3}$, а преюдициальность является неотъемлемым свойством обязательной силы судебного акта.

Тем более что в теории арбитражного процесса отмечается, что решения государственных судов и решения международных коммерческих арбитражей обладают равной юридической силой ${ }^{4}$, что позволяет сделать вывод о том, что решения международных коммерческих арбитражей также обладают преюдициальной силой.

Таким образом, цель настоящей статьи заключается в исследовании преюдициальной силы решений международных коммерческих арбитражей в соответствии с практикой российских и иностранных судов.

Настоящую работу хотелось бы начать со сравнения порядка исследования фактов в международном коммерческом арбитраже и государственном арбитражном суде.

\section{Порядок исследования фактов в международном коммерческом арбитраже и государственном арбитражном суде}

При разрешении спора в международном коммерческом арбитраже сторона приводит доказательства в поддержку своих требований, которые непосредственно исследуются арбитрами (cm. 27 Закона о $M K A)^{5}$.

Конвенция Организации Объединенных Наций о признании и приведении в исполнение иностранных арбитражных решений (Нью-Йорк, 10 июня 1958 г.).

Богатина Ю.Г. Оговорка о публичном порядке в международном частном праве: теоретические проблемы и современная практика. М.: Статут, 2010. С. 157.

Закон РФ от 07.07.1993 № 5338-1 (ред. от 03.12.2008) «О международном коммерческом арбитраже» (вме-
На основе представленных сторонами доказательств состав арбитража устанавливает доказанность определенных фактов, что отражается в мотивировочной части решения международного коммерческого арбитража.

Поскольку состав арбитража непосредственно исследует доказательства, а Правила беспристрастности и независимости третейских судей ${ }^{6}$ гарантируют независимость арбитров при рассмотрении спора, то это означает, что производство в международном коммерческом арбитраже основано на основных принципах арбитражного процесса - принципе состязательности ${ }^{7}$ и непосредственном исследовании доказательств.

Исходя из того, что третейское разбирательство основано на принципах состязательности и непосредственного исследования доказательств, установление истины в международном коммерческом арбитраже равноценно установлению истины в государственном арбитражном суде.

Принимая во внимание равноценность установления истины в международном коммерческом арбитраже и государственном суде, следует вывод о том, что отсутствуют препятствия для признания преюдициальной силы за решениями международных коммерческих арбитражей.

Тем более, что отсутствие закрепления преюдициальной силы решений международных коммерческих арбитражей приводит к тому, что государственные арбитражные суды игнорируют факты, установленные международным коммерческим арбитражем.

В литературе известны случаи, когда международный коммерческий арбитраж выносил решение о признании недействительной сделки купли-продажи, однако, государственный арбитражный суд, куда истец обращался с иском об истребовании своего имущества $(\mathrm{cm}$. 301 ГК РФ), отказывался признать преюдициальность этого решения, указывая, что истец должен снова обратиться в государственный

сте с «Положением о Международном коммерческом арбитражном суде при Торгово-промышленной палате Российской Федерации», «Положением о Морской арбитражной комиссии при Торгово-промышленной палате Российской Федерации») // Ведомости СНД и ВС РФ. 1993. № 32. Ст. 1240.

6 Приказ ТПП РФ от 27.08.2010 № 39 «О Правилах о беспристрастности и независимости третейских судей».

Суханов Е.А Третейские суды и предпринимательские споры //Право и экономика. 1998. № 2; также см. Курочкин С.А. Понятие и система принципов третейского разбирательства //Арбитражный и гражданский процесс. 2005. № 11; также см. Дегтярев С.Л., Емалтынов А.Р. Судебная деятельность как основа определения компетенции третейских судов по рассмотрению земельных споров // Арбитражный и гражданский процесс. 2012. № 4. С. 24-27. 
арбитражный суд с иском о признании указанной сделки недействительной ${ }^{8}$.

Подобная правоприменительная практика приводит к параллельному существованию на территории РФ решений государственного суда и международного коммерческого арбитража, по-разному квалифицирующие одни и те же фактические обстоятельства, что нарушает публичный порядок РФ в соответствии с Определением ВАС РФ от 27.08.2012 № ВАС-17458/11 (далее Определение ВАС РФ № ВАС-17458/11).

Вывод о наличии преюдициальной силы у решений международных коммерческих арбитражей вытекает из решения ЕСПЧ по делу Этеш Мимарлик Мюхендишлик против Турции ${ }^{9}$, в котором ЕСПЧ постановил, что государственные суды не вправе игнорировать факты, установленные иностранным юрисдикционным органом, поскольку это нарушает право стороны на справедливый суд, в соответствии ст. 6 Европейской Конвенции о защите прав человека и основных свобод $1950^{10}$.

Ниже приводится анализ указанных судебных актов, подтверждающих наличие преюдициальной силы у решений международных коммерческих арбитражей.

\section{Равная юридическая сила решений международных коммерческих арбитражей и государственных судов в соответствии с Определением ВАС РФ № ВАС-17458/11}

Последовательная практика государственных арбитражных судов указывает, что решение международного коммерческого арбитража и решение государственного суда представляют собой акты равной юридической силы в соответствии с Определением ВАС РФ № ВАС17458/11.

Обстоятельства цитируемого дела были таковы. Компания «Симан Франс» (Cement France) и ОАО Холдинговая Компания «Сибирский Цемент» заключили договор купли-продажи акций от 2008 г. Данный договор содержал оговорку о разрешении споров арбитражем

\footnotetext{
Сеглин Б.С. Исполнение решений Международного коммерческого арбитражного суда при ТПП РФ и иных международных арбитражных судов //Хозяйство и право. 1998. № 10.

Решение по делу «Этеш Мимарлик Мюхендишлик против Турции» (Case of Ates Mimarlik Muhendislik A.Ş v Turkey) Application no. 33275/05 цитируется по материалам с официальной базы данных ЕСПЧ //http://hudoc. echr.coe.int/sites/eng/pages/search.aspx?i=001-113441\#\{“it emid”:[“001-113441”]\}.

10 Конвенция о защите прав человека и основных свобод (Рим, 4 ноября 1950 г.) (с изменениями от 21 сентября 1970 г., 20 декабря 1971 г., 1 января, 6 ноября 1990 г. 11 мая 1994 г.) ETS № 005.
}

в соответствии с Арбитражным Регламентом МТП (Международной Торговой Палаты).

7 декабря 2012 г. состав арбитража вынес промежуточное решение, в котором постановил, что «договор купли-продажи акций является действительным...и был правомерно расторгнут истцом».

При обращении Симан Франс с заявлением о признании приведении в исполнение данного арбитражного решения, арбитражный суд Кемеровской области отказал в его признании, поскольку решением государственного арбитражного суда № A27-4626/2009 договор купли-продажи акций от 26.03.2008 был признан недействительным.

Определение суда первой инстанции было оставлено в силе кассационной и надзорной инстанциями. При этом состав ВАС РФ постановил, что признание данного арбитражного решения, вынесенного на основании недействительного договора, приведет к существованию на территории Российской Федерации судебных актов равной юридической силы (курсив А.К), содержащих взаимоисключающие выводы, что вступает в противоречие с принципом обязательности судебных актов (№ ВАС-17458/11).

Тем самым ВАС РФ, применяя Нью-Йоркскую Конвенцию 1958 г., пришел к выводу о том, что решения международных коммерческих арбитражей и государственных судов обладают равной юридической силой.

Исходя из принципа равной юридической силы и принципа обязательности иностранного арбитражного решения (cm. III Нью-Йоркской Конвенции 1958 2.), следует вывод, что арбитражное решение обладает всеми свойствами, что и решение государственного арбитражного суда ${ }^{11}$.

В теории арбитражного процесса указывается, что решение государственного суда обладает свойствами «неопровержимости, исполнимости, исключительности и преюдициальности» ${ }^{12}$.

Поскольку решения международных коммерческих арбитражей и решения государственных судов обладают равной юридической силой, то, исходя из определения обязатель-

11 При условии, что арбитражное решение было признано и приведено в исполнение на территории РФ - А.К.

12 Комментарий к Арбитражному процессуальному кодексу Российской Федерации (постатейный) / Н.В. Алексеева, А.А. Арифулин, Г.А. Жилин и др.; отв. ред. Д.А. Фурсов. М.: Проспект, 2011. подробнее см также Чечина Н.А. Норма права и судебное решение // Российский ежегодник гражданского и арбитражного процесса. 2002-2003. № 2/ Под ред. В.В. Яркова. СПб. 2004; Курочкин С.А. Государственные суды в третейском разбирательстве и международном коммерческом арбитраже. М.: Волтерс Клувер, 2008. 
ной силы решения международного коммерческого арбитража, свойство преюдициальности также распространяется на решения международных коммерческих арбитражей. Таким образом, решения международных коммерческих арбитражей обязательны при рассмотрении иных дел с участием данных сторон.

Предлагаемое толкование Нью-Йоркской Конвенции 1958 г. о наличии равной юридической силы у решения международного коммерческого арбитража и государственного суда находит широкую поддержку в международной практике применения Нью-Йоркской Конвенции 1958 г.

Так, суды США последовательно указывают на наличие преюдициальной силы у решений международных коммерческих арбитражей.

В решении по делу Panza vs. Amco Steel Corporation 3-й Апелляционный Суд США постановил, что «арбитражное решение, за исключением тех случаев, когда оно отменено, обладает такой же силой, как и решение государственного суда» ${ }^{13}$.

Развивая данный принцип, Суд Южного Округа Нью-Йорка в решении по делу Oinoussian Steamship Corporation of Panama v. Sabre Shipping Corporation ${ }^{14}$ постановил, что арбитражное решение, вынесенное в пределах арбитражной оговорки, обладает преюдициальной силой и эффектом res judicata.

Таким образом, международная практика применения Нью-Йоркской Конвенции 1958 г. свидетельствует о наличии преюдициальной силы у решения международного коммерческого арбитража.

Тезис о наличии преюдициальной силы у решений международных коммерческих арбитражей находит существенную поддержку в российской науке международного частного права.

Н. Ю. Ерпылева, обосновывая необходимость признания преюдициальной силы за решениями международных коммерческих арбитражей отмечает, что развитие экономических связей между юридическими лицами из разных государств требует трансграничного признания правовых последствий юридических фактов ${ }^{15}$.

Вывод о наличии преюдициальной силы у решений международных коммерческих арби-

13208 F. Supp. 50 (W.D. Pa. 1962), aff'd, 816 F.2d 69 (3d Cir.), cert. denied, 375 U.S. 897 (1963).

14224 F. Supp. 807 (S.D.N.Y. 1963).

15 Ерпылева Н.Ю. Международный коммерческий арбитраж: институционно-нормативный механизм правового регулирования // Законодательство и экономика. 2011. № 1. С. 38-58. тражей содержится в работах В.В. Яркова ${ }^{16}$ и С. А Курочкина ${ }^{17}$.

Таким образом, вывод о наличии преюдициальной силы у решений международных коммерческих арбитражей вытекает из международной практики применения Нью-Йоркской Конвенции 1958 г. и из российской теории международного частного права.

Второй важный принцип, закрепленный в данном Определении, заключается в том, что существование на территории РФ актов равной юридической силы, содержащих взаимоисключающие выводы, несовместимо с публичным порядком РФ. Однако именно подобная ситуация возникает в случае, когда государственные суды игнорируют факты, установленные решением международного коммерческого арбитража.

Поскольку принцип недопустимости параллельного существования, в соответствии с Определением ВАС РФ, относится к числу основополагающих принципов российского права, то игнорирование фактов государственным арбитражным судом фактов, установленных международным коммерческим арбитражем, нарушает указанный принцип.

Очевидно, что решение государственного суда, нарушающее основополагающие принципы российского права, не может рассматриваться как законное и обоснованное в соответствии с п. 3 ст. 15 АПК.

\section{Преюдициальная сила решений международных коммерческих арбитражей, в соответствии с решением ЕСПЧ по делу Этеш Мимарлик Мюхендишлик против Турции}

Вывод о том, что решение международного коммерческого арбитража обладает преюдициальной силой, следует также из решения ЕСПЧ по делу Этеш Мимарлик Мюхендишлик против турции ${ }^{18}$.

В решении по данному делу ЕСПЧ постановил, что государственный суд не вправе игнорировать факты, установленные решением иностранного юрисдикционного органа, поскольку это нарушает право стороны на спра-

16 Подробнее см Ярков, В. В. (Владимир Владимирович) Юридические факты в цивилистическом процессе М. Инфотропик Медиа, 2012.

17 Курочкин С.А. Государственные суды в третейском разбирательстве и международном коммерческом арбитраже. М.: Волтерс Клувер, 2008. С. 129-133.

18 Case of Ates Mimarlik Muhendislik A.Ş v. Turkey (Application no. 33275/05 цитируется по материалам с официальной базы данных ЕСПЧ http://hudoc.echr. coe.int/sites/eng/pages/search.aspx?i=001-113441\#\{“item id":[“001-113441”]\}. 
ведливый суд, в соответствии со ст. 6 Европейской Конвенции о защите прав человека и основных свобод $1950 \Gamma^{19}$.

Несмотря на то, что в данном деле рассматривался вопрос об обязательности фактов, установленных иностранным судебным решением, выводы, изложенные в нем, распространяются на преюдициальную силу решений международных коммерческих арбитражей.

Подобный вывод следует из решения ЕСПЧ по делу Риджент Компани против Украины ("Regent Company vs. Ukraine") ${ }^{20}$, в соответствии с которым понятие «суд» (ст. 6 Европейской Конвенции) включает в себя не только государственные суды, но и негосударственные органы по разрешению споров - в первую очередь международный коммерческий арбитраж.

Из обстоятельств данного дела следует, что между истцом - подрядчиком (Турция) и ответчиком (Правительство ФРГ) был заключен договор подряда с оговоркой о подсудности споров коммерческому суду г. Берлин (kammergerightshoff- прим. А.К).

Расторжение данного договора ответчиком послужило основанием для обращения истца в коммерческий суд г. Берлин. В своем решении коммерческий суд Берлина указал, что расторжение договора было правомерно, что не затрагивает право истца на оплату работ, осуществленных до расторжения договора, в соответствии с расчетом истца.

Ответчик с расчетом истца не согласился и уплатил лишь часть от данной суммы.

В связи с наличием задолженности по оплате выполненных работ истец обратился в торговый суд первой инстанции г. Стамбул (asliye ticaret mahkemesi - прим. A.K) с заявлением о признании и приведении в исполнение решения коммерческого суда Берлина и с иском о взыскании неосновательного обогащения в размере неоплаченной суммы работ.

Торговый суд г. Стамбул, приведя в исполнение решение коммерческого суда г. Берлин, отказал в удовлетворении иска о взыскании неосновательного обогащения, указав, что факты, установленные коммерческим судом г. Берлин, не

\footnotetext{
19 «Конвенция о защите прав человека и основных свобод» (Заключена в г. Риме 04.11.1950) (с изм. от 13.05.2004) (вместе с «Протоколом [№ 1]» (Подписан в г. Париже 20.03.1952), «Протоколом № 4 об обеспечении некоторых прав и свобод помимо тех, которые уже включены в Конвенцию и первый Протокол к ней» (Подписан в г. Страсбурге 16.09.1963), «Протоколом № 7» (Подписан в г. Страсбурге 22.11.1984)).

20 Case of Regent Company vs Ukraine Application no. $\quad 773 / 03$ http://hudoc.echr.coe.int/sites/eng/Pages/ search.aspx\#\{“fulltext":["regent company"],"documentco llectionid2”:[“GRANDCHAMBER'”CHAMBER”],"item id”:[“001-85681”]\}.
}

являются обязательными при разрешении спора о взыскании неосновательного обогащения, поскольку предметы обращения в коммерческий суд г. Берлин и торговый суд г. Стамбул различаются. (В коммерческий суд г. Берлин истец обратился с иском о признании действительным/недействительным договора, в то время как истец обратился в торговый суд г. Стамбул с иском о взыскании неосновательного обогащения).

Истец, считая неправомерным отказ торгового суда Стамбула в разрешении дела в соответствии с фактами, установленными решением иностранного суда, обратился в Европейский Суд по правам человека. При этом истец указал, что отказ в придании преюдициальной силы решению иностранного суда нарушает его право в соответствии со ст. 6 Европейской Конвенции на рассмотрение дела справедливым судом в соответствии с фактическими обстоятельствами дела.

Европейский Суд по правам человека, признавая нарушение права истца на справедливый суд, указал, что наличие признанного и приведенного в исполнение решения иностранного суда создало у истца разумные ожидания, что суд страны признания и приведения в исполнение при рассмотрении иных споров между сторонами будет исходить из фактов, установленных данным решением иностранного суда.

Комментируя данное решение ЕСПЧ, необходимо отметить, что, в соответствии с данным решением, действие иностранного судебного акта также распространяется на органы страны признания и приведения в исполнение, тем самым расширяя обязательность судебного акта. Тем самым, государственный суд страны признания и приведения в исполнение не вправе игнорировать факты, установленные решением иностранного юрисдикционного органа.

Поскольку решения ЕСПЧ применяются государственными судами РФ напрямую (ФЗ «O ратификации Конвенции о защите прав человек $\left.{ }^{21} »\right)$ существуют разумные ожидания полагать, что выводы ЕСПЧ по делу «Этеш $M$ Ммарлик Мюхендишлик против Турции» будут применены при рассмотрении соответствующих споров (в первую очередь при производстве в порядке надзора - n. $3 \mathrm{~cm} .304$ АПК).

И таким образом, решение ЕСПЧ по делу «Этеш Мимарлик Мюхендишлик против Турции» должно сыграть важную роль в области признания и приведения в исполнение иностранных арбитражных решений в РФ.

21 Федеральный закон от 30.03.1998 № 54-Ф3 «О ратификации Конвенции о защите прав человека и основных свобод и Протоколов к ней». "Собрание законодательства РФ», 06.04.1998, № 14, ст. 1514 //Российская газета. 1998. 7 апреля. 


\section{Выводы}

Существующее регулирование преюдициальной силы международных коммерческих арбитражей не соответствует практике применения ст. III Нью-Йоркской Конвенции, в соответствии с Определением ВАС РФ № ВАС-17458/11.

В указанном Определении ВАС РФ, применяя Нью-Йоркскую Конвенцию 1958, постановил, что решения международных коммерческих арбитражей и решения государственных арбитражных судов обладают равной юридической силой. Исходя из указания ВАС о равной юридической силе решений международных коммерческих арбитражей и государственных судов, следует вывод, что свойство преюдициальности распространяется на решения международных коммерческих арбитражей.

Кроме того, отсутствие закрепления в АПК ( а также ГПК) преюдициальной силы решений международных коммерческих арбитражей приводит к существованию на территории РФ двух актов равной юридической силы, что нару- шает публичный порядок РФ в соответствии с Определением ВАС РФ №-17458/11, поскольку порождает неопределённость в правах лица.

Решение ЕСПЧ по делу Этеш Мимарлик Мюхендишлик против Турции также свидетельствует о наличии преюдициальной силы у решений международных коммерческих арбитражей, поскольку в указанном решении устанавливается, что государственный суд не вправе игнорировать факты, установленные решением иностранного юрисдикционного органа. При этом ЕСПЧ подчеркнул, что подобное игнорирование нарушает право стороны на справедливый суд, в соответствии со ст. 6 Европейской Конвенции о защите прав человека и основных свобод 1950 г.

Остается надеяться, что российским законодателем будут приняты соответствующие поправки в АПК и ГПК, направленные на придание преюдициальной силы решениям международных коммерческих арбитражей и устранение существования взаимоисключающих актов равной юридической силы.

\section{Библиография}

1. Ярков, В. В. Юридические факты в цивилистическом процессе - М.: Инфотропик Медиа, 2012.

2. Скворцов, О.Ю. Третейское разбирательство предпринимательских споров в России: Проблемы, тенденции, перспективы М.:Волтерс Клувер, 2005.

3. Скворцов О.Ю. О некоторых вопросах взыскания убытков в третейском судопроизводстве // Убытки и практика их возмещения: Сборник статей /отв. ред. М.А. Рожкова. М.: Статут, 2006.

4. Курочкин С.А. Государственные суды в третейском разбирательстве и международном коммерческом арбитраже. М.: Волтерс Клувер, 2008.

5. Березий А.Е., Мусин В.А. О преюдиции судебных актов //Вестник ВАС РФ. 2001, № 6.

6. Новоселова Л.А., Рожкова М.А. К вопросу о силе судебных актов арбитражного суда //Вестник ВАС РФ. 2003. № 5.

7. Ерпылева Н.Ю. Международный коммерческий арбитраж: институционно-нормативный механизм правового регулирования // Законодательство и экономика. 2011. № 1.

8. Сеглин Б.С. Исполнение решений Международного коммерческого арбитражного суда при ТПП РФ и иных международных арбитражных судов //Хозяйство и право. 1998. № 10.

\section{References}

1. Yarkov, V. V. Yuridicheskie fakty v tsivilisticheskom protsesse - M. : Infotropik Media, 2012.

2. Skvortsov, O.Yu. Treteiskoe razbiratel'stvo predprinimatel'skikh sporov v Rossii: Problemy, tendentsii, perspektivy M.:Volters Kluver, 2005.

3. Skvortsov 0.Yu. O nekotorykh voprosakh vzyskaniya ubytkov v treteiskom sudoproizvodstve // Ubytki i praktika ikh vozmeshcheniya: Sbornik statei /otv. red. M.A. Rozhkova. M.: Statut, 2006.

4. Kurochkin S.A. Gosudarstvennye sudy v treteiskom razbiratel'stve i mezhdunarodnom kommercheskom arbitrazhe. M.: Volters Kluver, 2008.

5. Berezii A.E., Musin V.A. 0 preyuditsii sudebnykh aktov //Vestnik VAS RF. 2001, № 6.

6. Novoselova L.A., Rozhkova M.A. K voprosu o sile sudebnykh aktov arbitrazhnogo suda //Vestnik VAS RF. 2003. № 5.

7. Erpyleva N.Yu. Mezhdunarodnyi kommercheskii arbitrazh: institutsionno-normativnyi mekhanizm pravovogo regulirovaniya // Zakonodatel’stvo i ekonomika. 2011. № 1.

8. Seglin B.S. Ispolnenie reshenii Mezhdunarodnogo kommercheskogo arbitrazhnogo suda pri TPP RF i inykh mezhdunarodnykh arbitrazhnykh sudov //Khozyaistvo i pravo. 1998. № 10. 